\title{
Synthesis and Neurotropic Activity of Novel Quinoline Derivatives
}

\author{
Edmunds Lukevics*, Izolda Segal, Alla Zablotskaya and Skaidrite Germane \\ Latvian Institute of Organic Synthesis, 21 Aizkraukles str., LV-1006, Riga, Latvia \\ Fax: (371)-7821038; E-mail: AEZ@osi.lanet.lv
}

Received: 12 December 1996 / Accepted: 15 August 1997 / Published: 25 November 1997

\begin{abstract}
Hydroxyalkyl and carboxyalkyl derivatives of silatetrahydroisoquinoline, tetrahydroisoquinoline and tetrahydroquinoline have been synthesized. Their neurotropic activity has been investigated.
\end{abstract}

Keywords: Silatetrahydroquinoline, trialkylsiloxyethylisoquinolines, tetrahydroquinolyl amino acids, neurotropic activity.

\section{Introduction}

We have shown [1,2] that the silylation increases the psychotropic activity of aminoalkanols and their salts (choline agonist/antagonist depending on the test). The mechanism of action of the silylated compounds can be stipulated by the overcoming the lipophilic barrier [3]. To verify this finding we have synthesized amino acids (Scheme 1-3) and investigated their neurotropic activity and acute toxicity in comparison with organosilicon derivatives of heterocyclic aminoalkanols $(\mathbf{3}, \mathbf{4}, \mathbf{7 - 9}, \mathbf{1 2}$, 13) [4].

\section{Results and Discussion}

Silatetrahydroisoquinoline $\mathbf{1 4}$ has been synthesized by the cyclization of the previously obtained dimethylchloromethyl(2-bromomethylphenyl)silane with glycine ethyl ester (Scheme 1).
Interaction of 1,2,3,4-tetrahydroquinoline or isoquinoline with ethyl chloroacetate resulted in the corresponding ethyl esters 15, 20 which further were converted into methiodides 16, 21 and other derivatives as amide 19, sodium salt $\mathbf{1 8}$ and hydrochloride of tetrahydroisoquinolyl acetic acid $\mathbf{1 7}$ (Schemes 2 and 3).

Psychotropic activity of the compounds synthesized and the corresponding methiodides have been examined on mice (i.p. administration in the doses of $50 \mathrm{mg} / \mathrm{kg}$ ) along the number of tests as rotating rod, tube, rectal temperature, traction, hypoxia, hexenal and ethanol anaesthesia, corazole convulsions, phenamine hyperactivity.

The majority of the studied compounds has been found to possess the sedative activity.

Comparison of sila-tetrahydroisoquinoline, tetrahydroisoquinoline and tetrahydroquinoline derivatives has been carried out. Tetrahydroisoquinoline derivatives 3-6, 16-19 were more active in locomotor

\footnotetext{
* To whom correspondence should be addressed.

(C) 1997 MDPI. All rights reserved
} 
activity and muscle tone tests, in hexenal and ethanol (prolonging action) anaesthesia, corazole convulsions (tonic phase) and phenamine hyperactivity (as antagonists).<smiles>[R]OCCN1Cc2ccccc2[Si](C)(C)C1</smiles><smiles>[R]OCCN1CCc2ccccc2C1</smiles>
$5, \mathrm{R}=\mathrm{H}$
6, $\mathrm{R}=\mathrm{H}$ (+Methyliodide)
7, $\mathrm{R}=\mathrm{SiMe}_{3}$
$\mathbf{8}, \mathrm{R}=\mathrm{SiEt}_{3}$
9, $\mathrm{R}=\mathrm{SiEt}_{3}$ (+Methyliodide)<smiles>[R]OCCN1CCCc2ccccc21</smiles>

10, $\mathrm{R}=\mathrm{H}$

11, $\mathrm{R}=\mathrm{H}$ (+Methyliodide)

12, $\mathrm{R}=\mathrm{SiMe}_{3}$

13, $\mathrm{R}=\mathrm{SiEt}_{3}$

Silatetrahydroisoquinoline derivatives 1-3, 14 were more active in ethanol anaesthesia (as antagonists). Tetrahydroquinoline derivatives 10-13, 21 were more active in corazole convulsions (clonic phase). Silatetrahydroisoquinoline (14) and tetrahydroquinoline (21) derivatives had the same high level of activity in hypoxia test.

Comparison of aminoalkanol and amino acid derivatives has demonstrated that aminoalkanols 1-13 and amino acid derivatives 14-21 appeared to be of approximately equal potency in locomotor activity and muscle tone tests, in tests of hypoxia and hexenal anaesthesia.
Amino acids prolonged the ethanol anaesthesia, while aminoalkanols reduced it (excluding compound 9). The action of aminoalkanols was appreciable both in clonic and tonic phase of corazole convulsions test, amino acids were active only in tonic phase. Amino acids were a little more active as the phenamine antagonists.

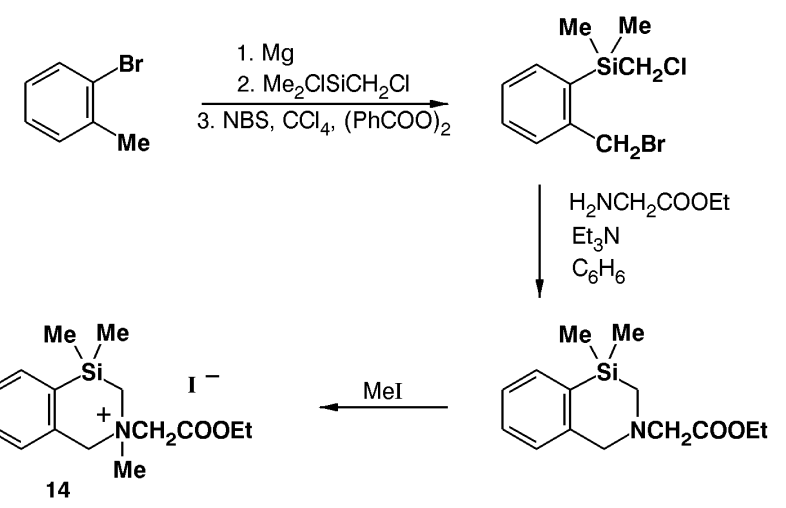

Scheme 1.

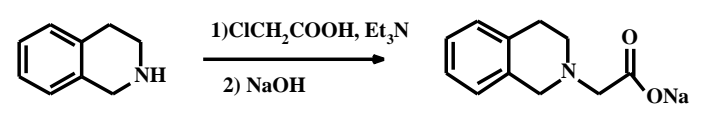

18

$\mathrm{ClCH}_{2} \mathrm{COOEt}, \mathrm{Et}_{3} \mathrm{~N}$

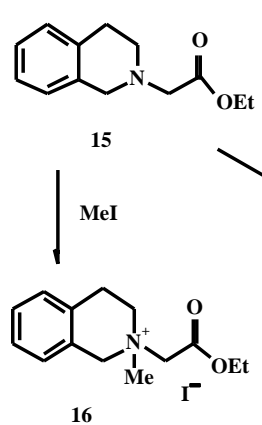

$\mathrm{NH}_{4} \mathrm{OH}$, conc.

19

Scheme 2.

The neurotropic activity data for the most active tetrahydro[sila,iso]quinolyl aminoalkanols and amino acids exhibiting the best results in any of the tests are presented in Table 1.

Methiodides of ethyl [N-(4,4-dimethyl-4-sila-1,2,3,4tetrahydroisoquinolyl)]- (14) and $\quad[\mathrm{N}-(1,2,3,4-$ 
tetrahydroquinolyl)]acetates (21) were highly effective against hypoxia $(\sim 180 \%)$.

Sodium salt of [N-(1,2,3,4-tetrahydroisoquinolyl)] acetic acid (18) was the most active in the test of hexenal anaesthesia, prolonging the hexenal action by 1.85 times. This compound has been found to be less toxic compound $\left(\mathrm{LD}_{50}=3550 \mathrm{mg} \cdot \mathrm{kg}^{-1}\right)$.

Aminoalkanol derivatives were the most active in the test of ethanol anaesthesia as ethanol antagonists and agonists as well. N-(2'-Hydroxyethyl)-4,4-dimethyl-4-sila1,2,3,4-tetrahydroisoquinoline (1) and trialkylsilyl ethers $(4,12,13)$ shortened the duration of ethanol action (33$42 \%)$. On the contrary, methiodide derived from N-(2'triethylsiloxyethyl)-1,2,3,4-tetrahydroisoquinoline prolonged this kind of anaesthesia $(280.5 \%$, control $100 \%)$.

N-(2'-Hydroxyethyl)-4,4-dimethyl-4-sila-1,2,3,4-tetrahydroisoquinoline (1), N-(2'-hydroxyethyl)-1,2,3,4tetrahydroisoquinoline (5) and N-(2'-trimethylsiloxyethyl)1,2,3,4-tetrahydroquinoline (12) increased the threshold of corazole convulsions up to $323 \%$ in clonic phase and up to $247 \%$ in tonic phase.

Hydrochloride of 2-[N-(1,2,3,4-tetrahydroisoquinolyl)] acetic acid (17) was the most active as phenamine antagonist.

\section{Conclusions}

Depending on the nature of a hetetrocycle, Nsubstituent and the presence of a silicon atom in the molecule, the compounds under study exhibit a predominant psychotropic activity: tetrahydroisoquinolines show a sedative activity; the silatetrahydroisoquinoline derivatives - an antihypnotic action (shortening of ethanolinduced sleeping time); tetrahydroquinolines anticonvulsant (pentylenetetrazol-convulsion test) effects.

The data obtained indicate a usefulness of rational design for novel neuroprotective compounds in a series of the silicon-containing heterocyclic derivatives.<smiles>c1ccc2c(c1)CCCN2</smiles>

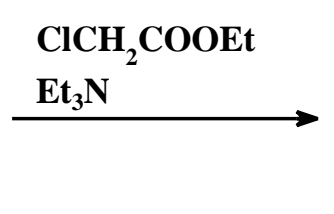<smiles>CCOC(=O)CN1CCCc2ccccc21</smiles>

20

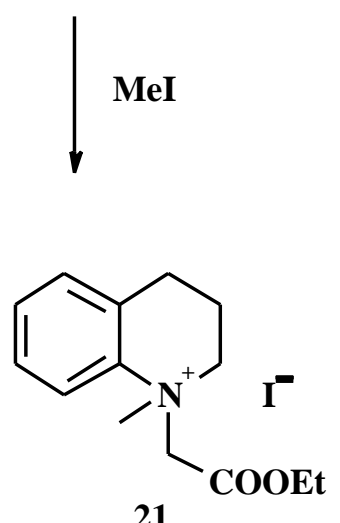

Scheme 3. 
Table 1. Neurotropic activity of the most active tetrahydro[sila,iso]quinolyl aminoalkanol and amino acid derivatives. $(\mathrm{M} \pm \mathrm{m}) \%$ to control $(100 \%)$.

\begin{tabular}{|c|c|c|c|c|c|c|}
\hline Compd. & Hypoxia & $\begin{array}{l}\text { Hexenal } \\
\text { anaesthesia } \\
\text { (prolongation) }\end{array}$ & $\begin{array}{l}\text { Ethanol } \\
\text { anaesthesia }\end{array}$ & $\begin{array}{l}\text { Corazole } \\
\text { convulsions } \\
\text { clonic/tonic } \\
\end{array}$ & $\begin{array}{l}\text { Phenamine } \\
\text { hyperactivity } \\
\text { (as antagonist) }\end{array}$ & $\mathrm{LD}_{50}, \mathrm{mg} \cdot \mathrm{kg}^{-1}$ \\
\hline 14 & $182.6^{*}$ & $150.0^{*}$ & 113.9 & $98.5 / 155.4^{*}$ & 106.8 & $44.7(31.3-59.7)$ \\
\hline 1 & $132.0^{*}$ & 120.0 & $35.7 *$ & $171.8 * / 246.7 *$ & 127.6 & $112(79-147)$ \\
\hline 4 & 116.1 & $161.1^{*}$ & 33.0* & $160.3 * / 168.5^{*}$ & $79.3 *$ & $178(136-230)$ \\
\hline 17 & $135.3^{*}$ & 121.2 & 89.3 & $75.1 / 334.1^{*}$ & $45.2 *$ & $815(567-1110)$ \\
\hline 18 & $140.9^{*}$ & $184.7 *$ & $132.5^{*}$ & $88.7 / 270.3^{*}$ & 83.2 & $\mathbf{3 5 5 0}(2020-5080)$ \\
\hline 5 & $135.2^{*}$ & $107.0^{*}$ & $59.8^{*}$ & $206.1 * / 212.6 *$ & $67.5^{*}$ & 282 \\
\hline 9 & $136.7^{*}$ & $172.2^{*}$ & $280.5^{*}$ & $164.5 * / 224.8^{*}$ & 117.4 & $45(31-60)$ \\
\hline 21 & $184.4^{*}$ & $156.2 *$ & $120.2^{*}$ & $104.2 / 104.9$ & $75.8^{*}$ & $41.0(26.8-55.2)$ \\
\hline 12 & $121.7 *$ & 110.0 & 41.9* & $323.5 * / 195.4 *$ & 108.8 & $755(348-1215)$ \\
\hline 13 & $129.9 *$ & 110 & $40.2 *$ & $140.7 * / 119.2$ & 101.5 & $>2000$ \\
\hline
\end{tabular}

\section{Experimental Section}

\section{General methods}

Melting points were determined on a Boetius table and were uncorrected. NMR spectra were obtained on a Bruker WH-90/DS spectrometer operating at $90 \mathrm{MHz}$ using $\mathrm{CDCl}_{3}$ and DMSO- $\mathrm{d}_{6}$ as solvents and $\mathrm{Me}_{4} \mathrm{Si}$ as internal standart. IR spectra were recorded for nujol mulls on a Perkin-Elmer 580B spectrometer. GLC analysis was conducted on a Chrom-42 instrument equipped with a flame-ionization detector using a glass column $(1.2 \mathrm{~m} \times 3$ $\mathrm{mm}$ ) packed with 5\% OV-17 on Chromosorb W-AW (6080 mesh).

General procedure for the synthesis of ethyl 2-[N-(1,2,3,4tetrahydroisoquinolyl- (15) and tetrahydroquinolyl)]acetate (20)

Ethyl chloroacetate $(12.2 \mathrm{~g}, 100 \mathrm{mmol})$ in hexane (10 $\mathrm{mL}$ ) was dropped to the stirred and slightly heated 
solution of 1,2,3,4-tetrahydroisoquinoline or 1,2,3,4tetrahydroquinoline $(13.3 \mathrm{~g}, 100 \mathrm{mmol})$ and triethylamine $(11.1 \mathrm{~g}, 15.2 \mathrm{~mL}, 110 \mathrm{mmol})$ in hexane $(20 \mathrm{~mL})$. After $3 \mathrm{~h}$ heating the formation of the product was established by GLC. After $17 \mathrm{~h}$ at room temperature the solid was removed by filtration. The solution was concentrated in vacuo. The crude material was purified by vacuum distillation.

Ethyl 2-[N-(1,2,3,4-tetrahydroisoquinolyl)]acetate (15): yield 75\%; bp 152-154 ${ }^{\circ} \mathrm{C} / 4 \mathrm{~mm} ;{ }^{1} \mathrm{H} \mathrm{NMR}\left(\mathrm{CDCl}_{3}\right) \delta: 6.98$ $(\mathrm{m}, 4 \mathrm{H}, 5,6,7,8-\mathrm{H}), 4.13\left(\mathrm{q}, 2 \mathrm{H}, \mathrm{OCH}_{2}\right), 3.73(\mathrm{~s}, 2 \mathrm{H}$, $\mathrm{ArCH}_{2} \mathrm{~N}$ ), 3.31 (s, 2H, $\mathrm{NCH}_{2} \mathrm{CO}$ ), 2.84 (m, 4H, 3,4- $\mathrm{CH}_{2}$ ), $1.12\left(\mathrm{t}, 3 \mathrm{H}, \mathrm{CH}_{3}\right)$.

Ethyl 2-[N-(1,2,3,4-tetrahydroquinolyl)]acetate (20): yield 63\%; bp 123-127 ${ }^{\circ} \mathrm{C} / 1.5 \mathrm{~mm} ;{ }^{1} \mathrm{H}$ NMR $\left(\mathrm{CDCl}_{3}\right) \delta$ : 6.29-7.13 (m, 4H, 5,6,7,8-H), 4.17 (q, 2H, $\mathrm{OCH}_{2}$ ), 3.96 (s, $2 \mathrm{H}, \mathrm{NCH}_{2} \mathrm{CO}$ ), 3.38 (t, 2H, $\mathrm{NCH}_{2}$ cycl.), 2.79 (t, 2H, 4$\left.\mathrm{CH}_{2}\right), 2.00\left(\mathrm{~m}, 2 \mathrm{H}, 3-\mathrm{CH}_{2}\right), 1.26\left(\mathrm{t}, 3 \mathrm{H}, \mathrm{CH}_{3}\right)$.

Methiodide of ethyl 2-[N-(4,4-dimethyl-4-sila-1,2,3,4tetrahydroisoquinolyl)]acetate (14)

Dimethylchloromethyl (2-bromomethylphenyl)silane $(2.80 \mathrm{~g}, 10 \mathrm{mmol})$ was dropped to a stirred mixture of glycine ethyl ester $(1.27 \mathrm{~g}, 12 \mathrm{mmol})$ and triethylamine $(2.2 \mathrm{~g}, 3.0 \mathrm{~mL}, 22 \mathrm{mmol})$ in benzene $(15 \mathrm{~mL})$. The reaction mixture was heated at $75{ }^{\circ} \mathrm{C}$ for $12 \mathrm{~h}$ and allowed to stand at room temperature for $17 \mathrm{~h}$. Then solution was decantated, the solid was dissolved in chloroform, reprecipitated by ether and filtered. The solutions were combined and the solvent was evaporated. Methyl iodide $(6.8 \mathrm{~g}, 3.0 \mathrm{~mL}, 48 \mathrm{mmol})$ was added to the residue $(2.35$ $\mathrm{g})$. The reaction mixture was allowed to stand for 3 days, the solid was separated by decantation and crystallized from ether and ethanol mixture to give 14 (1.02 g, 25\%).

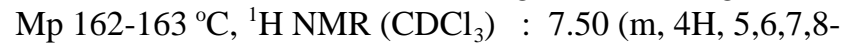
$\mathrm{H}), 5.34$ (q, 2H, $\left.\mathrm{ArCH}_{2} \mathrm{~N}\right), 4.96\left(\mathrm{q}, 2 \mathrm{H}, \mathrm{N}^{+} \mathrm{CH}_{2} \mathrm{CO}\right), 4.24$ (q, 2H, $\left.\mathrm{OCH}_{2}\right), 4.00\left(\mathrm{q}, 2 \mathrm{H}, \mathrm{SiCH}_{2}\right), 3.69\left(\mathrm{~s}, 3 \mathrm{H}, \mathrm{N}^{+} \mathrm{CH}_{3}\right)$, $1.26(\mathrm{t}, 3 \mathrm{H}, \mathrm{Me}), 0.51\left(\mathrm{~d}, 6 \mathrm{H}, \mathrm{SiMe}_{2}\right) . \mathrm{IR}\left(\mathrm{cm}^{-1}\right): 1750$, $\mathrm{C}=\mathrm{O}$.

Methiodide of ethyl 2-[N-(1,2,3,4-

tetrahydroisoquinolyl)]acetate (16)

A solution of ethyl ester $\mathbf{1 5}(10 \mathrm{mmol})$ in hexane (20 $\mathrm{mL}$ ) was refluxed for $6 \mathrm{~h}$ and allowed to stand at room temperature for $20 \mathrm{~h}$. The reaction mixture was filtered and the solid was crystallized from abs. ether/ethanol mixture (yield 50\%). Mp 164-165 ${ }^{\circ} \mathrm{C},{ }^{1} \mathrm{H}$ NMR $\left(\mathrm{CDCl}_{3}\right) \delta$ : $(\mathrm{m}, 4 \mathrm{H}$, 5,6,7,8-H), 5.17 (q, 2H, $\left.\mathrm{ArCH}_{2} \mathrm{~N}\right), 4.97$ (q, 2H, $\mathrm{N}^{+} \mathrm{CH}_{2} \mathrm{CO}$ ), 4.04-4.51 (m, 4H, $\left.\mathrm{OCH}_{2}+3-\mathrm{CH}_{2}\right), 3.62\left(\mathrm{~s}, 3 \mathrm{H}, \mathrm{N}^{+} \mathrm{Me}\right), 3.16$ (t, $\left.2 \mathrm{H}, 4-\mathrm{CH}_{2}\right), 1.27\left(\mathrm{t}, 3 \mathrm{H}, \mathrm{CH}_{3}\right)$; IR $\left(\mathrm{cm}^{-1}\right) 1740, \mathrm{C}=\mathrm{O}$.

Hydrochloride of 2-[N-(1,2,3,4-

tetrahydroisoquinolyl)]acetic acid (17)
Conc. hydrochloric acid (4 mL) was dropped carefully to the stirred ethyl ester $15(1.50 \mathrm{~g}, 6.8 \mathrm{mmol})$, the stirring was continued at reflux for $4 \mathrm{~h}$. The reaction mixture was filtered, and the solid was crystallized from ether/ethanol mixture to give 17 (0.97 g, 62\%). $\mathrm{Mp} 243{ }^{\circ} \mathrm{C}$ (decomp.). ${ }^{1} \mathrm{H}$ NMR (DMSO-d $)_{6}$ ) $: 11.3\left(\right.$ br s, $\left.1 \mathrm{H}, \mathrm{N}^{+} \mathrm{H}\right), 7.21(\mathrm{~m}, 4 \mathrm{H}$, 5,6,7,8-H), 4.48 (s, 2H, $\left.\mathrm{ArCH}_{2} \mathrm{~N}\right), 4.21$ (s, 2H, $\left.\mathrm{NCH}_{2} \mathrm{CO}\right)$, $3.57\left(\mathrm{t}, 2 \mathrm{H}, 3-\mathrm{CH}_{2}\right), 3.11\left(\mathrm{t}, 2 \mathrm{H}, 4-\mathrm{CH}_{2}\right)$.

\section{Sodium salt of 2-[N-(1,2,3,4-tetrahydroisoquinolyl)acetic acid (18)}

Chloroacetic acid $(4.7 \mathrm{~g}, 50 \mathrm{mmol})$ was added to a stirred, cooled solution of 1,2,3,4-tetrahydroisoquinoline $(6.6 \mathrm{~g}, 4.2 \mathrm{~mL}, 50 \mathrm{mmol})$ and triethylamine $(5.0 \mathrm{~g}, 7.0 \mathrm{~mL}$, $50 \mathrm{mmol})$ in chloroform $(10 \mathrm{~mL})$. The reaction mixture was refluxed for $5 \mathrm{~h}$, then cooled and filtered. Filtrate was worked up with $10 \% \mathrm{NaOH}(10 \mathrm{~mL})$. The aqueous layer was washed with ether and the formed precipitate was collected by filtration and crystallized from mixture ethanol/water to give 18 (3.2 g, 30\%). Mp 270-272 ${ }^{\circ} \mathrm{C} .{ }^{1} \mathrm{H}$ NMR $\left(\mathrm{D}_{2} \mathrm{O}\right) \delta: 7.18(\mathrm{~m}, 4 \mathrm{H}, 5,6,7,8-\mathrm{H}), 3.69(\mathrm{~s}, 2 \mathrm{H}$, $\left.\mathrm{NCH}_{2} \mathrm{CO}\right), 2.87$ (m, 4H, 3,4- $\mathrm{CH}_{2}$ ).

\section{Amide of 2-[N-(1,2,3,4-tetrahydroisoquinolyl)]acetic acid} (19)

A mixture of ester $15(0.88 \mathrm{~g}, 4 \mathrm{mmol})$ and conc. $\mathrm{NH}_{4} \mathrm{OH}(3 \mathrm{~mL})$ was heated in the "Pierce" reactor for $4 \mathrm{~h}$ and allowed to stand at room temperature for $18 \mathrm{~h}$. The reaction mixture was filtered, the solid was washed with water until neutral $\mathrm{pH}$ and then - with small quantity of ether to give $19(0.2 \mathrm{~g}, 26 \%)$. Mp 153-154 ${ }^{\circ} \mathrm{C}$. ${ }^{1} \mathrm{H}$ NMR

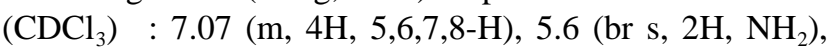
3,71 (s, 2H, $\left.\mathrm{ArCH}_{2} \mathrm{~N}\right), 3.17$ (s, 2H, $\left.\mathrm{NCH}_{2} \mathrm{CO}\right), 2.88$ (m, $4 \mathrm{H}, 3,4-\mathrm{CH}_{2}$ ).

\section{Methiodide of ethyl 2-[N-(1,2,3,4- tetrahydroquinolyl)]acetate (21)}

This was synthesized without solvent at room temperature. Mp 112-114 ${ }^{\circ} \mathrm{C}$; yield $16 \% .{ }^{1} \mathrm{H} \mathrm{NMR}\left(\mathrm{CDCl}_{3}\right)$ $\delta: \quad 7.23-8.27(\mathrm{~m}, \quad 4 \mathrm{H}, \quad 5,6,7,8-\mathrm{H}), \quad 5.89(\mathrm{~d}+\mathrm{d}, \quad 2 \mathrm{H}$, $\left.\mathrm{N}^{+} \mathrm{CH}_{2} \mathrm{CO}\right), 4.64\left(\mathrm{~m}, 2 \mathrm{H}, \mathrm{N}^{+} \mathrm{CH}_{2}\right.$ cycl.), 4.10 (m, 5H, $\left.\mathrm{OCH}_{2}+\mathrm{N}^{+} \mathrm{Me}\right), 3.08\left(\mathrm{t}, 2 \mathrm{H}, 4-\mathrm{CH}_{2}\right), 2.36\left(\mathrm{~m}, 2 \mathrm{H}, 3-\mathrm{CH}_{2}\right)$, $1.17(\mathrm{t}, 3 \mathrm{H}, \mathrm{Me})$; IR $\left(\mathrm{cm}^{-1}\right) 1750, \mathrm{C}=\mathrm{O}$.

\section{Pharmacological methods}

The neurotropic activity of the synthesized compounds was studied on BALB/c mice of both sexes weighing 18$23 \mathrm{~g}$ in winter season. The room temperature was maintained within the limits $21+2{ }^{\circ} \mathrm{C}$. Solutions of compounds in olive oil or aqueous suspensions of the remaining substances, prepared with the addition of 
Tween-80, were introduced intraperitoneally 30-45 min (the oily solutions $60 \mathrm{~min}$ ) before the test. The same volume of the sodium chloride isotonic solution was injected into the control animals. The effect of the substances injected in the doses of $50 \mathrm{mg} / \mathrm{kg}$ was compared in groups of animals, consisting of 6-8 individuals. The experimental data were treated statistically. The mean values of $\mathrm{LD}_{50}$ and $\mathrm{ED}_{50}$ for $12-25$ observations were determined by a rapid method given in [11]. The arithmetical means and their standard deviations $(\mathrm{M} \pm \mathrm{m})$ were calculated to assess the average duration of the anaesthetic effect of the hexenal and phenamine stereotypy, the protective properties in the corazol spasms and hypoxia, the degree of hypothermia. The significance of differences between mean values were assessed by Student's criterion: differences were considered as significant at a probability level $\mathrm{p}<0.05$.

The effect of the substances on the central nervous system was estimated:

- from their influence on the coordination of movements and the muscle tone by the tests "rotating rod" $(8 \mathrm{rpm}$ for 2 min on an Ugo Basile apparatus), "tube" (30 x $2 \mathrm{~cm}$ glass tube, $30 \mathrm{sec}$ ), and "tightening in crossbeam" ( $2 \mathrm{~mm}$ metal wire, $5 \mathrm{sec}$ );

- from the influence on the body temperature: by measuring the rectal temperature with an electric thermometer (the criterion for the test was a lowering of the temperature by $3{ }^{\circ} \mathrm{C}$ and more);

- from the analgesic effect, determined by the "hot plate" method;

- from the antispasmodic activity, estimated by the maximum electric shock test (a.c. current with an intensity of $50 \mathrm{~mA}$ and a frequency of 50 pulses/sec, duration of stimulation $0.2 \mathrm{sec}$ );

- from the corazol spasms caused by the intravenous titration with $1 \%$ corazol solution at a rate of $0.01 \mathrm{ml} / \mathrm{sec}$;

- from the influence on the duration of the hexenal anaesthesia (70 mg/kg, i.v.) and the ethanol anaesthesia ( $25 \%$ solution of ethanol i.a., the dose of $5 \mathrm{~g} / \mathrm{kg}$ );

- from the influence of the life time of animals under hypoxic hypoxia, created by placing the mouse in a separate chamber with a volume of $220 \mathrm{~cm}^{3}$ without absorption of $\mathrm{CO}_{2}$;
- from the the change in the locomotor activity, enforced by phenamine $(10 \mathrm{mg} / \mathrm{kg}$, s.c.).

The acute toxicity was determined by the intraperitoneal introduction of the investigated substances and by establishing the lethal dose $\left(\mathrm{LD}_{50}\right)$.

Acknowledgement: We are grateful to the Latvian Science Council (Grant 96-443) for the financial support.

\section{References}

1. Zablotskaya, A. E.; Germane, S. K.; Segal, I. D.; Lukevics, E. Latv. J. Chem. 1993, 79.

2. Lukevics, E.; Zablotskaya, A. E.; Germane, S. K.; Segal, I. D. Latv. J. Chem. 1994, 472.

3. Lukevics, E.; Zablotskaya, A. E. Metalloorg. Khim. 1993, 6, 263.

4. Lukevics, E.; Segal, I. D.; Zablotskaya, A. E.; Germane, S. K. Chem. Heterocycl. Compds. 1996, 793.

5. Lukevics, E.; Segal, I.; Lapina, T.; Boreko, E. I.; Vladyko, G. V.; Korobchenko, L. V.; Evstropov, A.N. Latv. PSR. Zinat. Akad. Vestis, Kim. Ser.1986, 720 .

6. Ferles, M.; Silhankova, A.; Kafka, S.; Taufmann, P.; Motacek, T. Coll. Czech. Chem. Commun. 1983, 48, 1759.

7. Aspro-Nicholas Ltd., Brit. 984, 361; CA, 1965, 62, P7737d.

8. Karimov, M.; Levkovich, M. G.; Leontjev, V. B.; Sadykov, A. S.; Aslanov, Kh.A.; Yunusov, T. K.; Sadykov, A. A. Khim. Prir. Soedin. 1974, 486.

9. Morphy, J. R.; Rankovic, Z.; Rees, D. C. Tetrahedron Lett. 1996, 37, 3209.

10. Bacon, E. R.; Daum, S. J.; Singh, B. PCT Int. Appl. WO 96 28, 429; CA, 1996, 125, P 301016 b

11. Germane, S. K.; Eberlinjsh, O. E.; Kozhuhov, A. N. In: Scientific and Methodological Aspects of Biological Study of Novel Drugs. Zinatne, Riga, 1987, 86 .

Sample Availability: Available from the authors. 